\title{
Osteosarkoma pada Anak di RS. Dr Cipto Mangunkusumo Jakarta
}

\author{
Tumpal Y Sihombing, * Endang Windiastuti, ** Djajadiman Gatot** \\ *SMF Kesehatan Anak RS Fatmawati Jakarta \\ ** Departemen Ilmu Kesehatan Anak RS Cipto Mangunkusumo Jakarta
}

\begin{abstract}
Latar belakang. Osteosarkoma merupakan tumor primer tulang yang paling sering dijumpai terutama pada remaja. Tata laksana osteosarkoma saat ini meliputi modalitas operasi dan kemoterapi yang diberikan pada preoperasi/neoajuvan maupun pasca operasi/adjuvan.

Tujuan. Mengetahui karakteristik pasien osteosarkoma untuk membantu mengembangkan pengelolaan pasien anak dengan osteosarkoma di Rumah Sakit Cipto Mangunkusumo (RSCM), Jakarta.

Metode. Penelitian retrospektif terhadap seluruh anak dengan osteosarkoma yang dirawat di Departemen Ilmu Kesehatan Anak FKUI-RSCM dari tahun 1998-2008. Data dikelompokkan berdasarkan umur, jenis kelamin, lokasi tumor, pemeriksaan penunjang, pemberian kemoterapi, metastasis, dan hasil akhir/outcome.

Hasil. Ditemukan 23 kasus osteosarkoma, yang berusia 9-16 tahun. Kadar alkalin fosfatase (ALP) dan laktat dehidrogenase (LDH) diperiksa pada 22 pasien, 20 pasien dengan ALP tinggi dan 15 pasien LDH tinggi. Pada 22 pasien dilakukan kemoterapi, 15 neoadjuvan, 5 adjuvan dan 2 mendapat kombinasi kemoterapi neoajuvan dan ajuvan. Sepuluh pasien diamputasi, 4 meninggal. Pada 5 pasien dilakukan limb sparing. Pada akhir pengamatan terdapat 10 pasien hidup terdiri dari 2 pasien telah selesai pengobatan dan 8 pasien masih dalam pengobatan. Lima pasien dengan metastasis ke paru, satu di antaranya meninggal.

Kesimpulan. Pada umumnya pasien datang dengan keadaan inoperable, meskipun demikian kemoterapi memberikan outcome yang lebih baik. (Sari Pediatri 2009;11(3):179-83).
\end{abstract}

Kata kunci: osteosarkoma, kemoterapi, neoajuvan, ajuvan

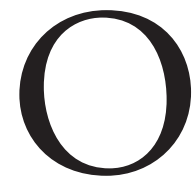

steosarkoma merupakan keganasan primer pada tulang yang paling sering dijumpai dan ditandai dengan adanya selsel mesenkim ganas yang memproduksi

\footnotetext{
Alamat korespondensi

Dr. Endang Windiastuti, SpA(K). Divisi Hematologi Onkologi Departemen Ilmu Kesehatan Anak FKUI- RSCM Jl. Salemba no. 6, Jakarta 10430. Telepon: 021-3907744, 31901170 Fax.021-3913982.
}

osteoid atau sel tulang imature. Insidens osteosarkoma diperkirakan sekitar 2-3 per 1 juta per tahun, pada remaja lebih tinggi yaitu 8-11 per 1juta per tahun, laki-laki 1,4 kali lebih sering mengalami osteosarkoma dibanding perempuan. ${ }^{1,2}$

Osteosarkoma dengan derajat keganasan tinggi sangat mudah menyebar. ${ }^{1,3,4}$ Dahulu angka survival lima tahun pasien osteosarkoma pada ekstremitas tanpa metastasis dengan operasi hanya 20\%. Dengan adanya kemoterapi 
neoajuvan dan ajuvan yang digunakan sejak awal tahun 1970an, angka survival pasien osteosarkoma meningkat sampai $60,1 \%$. Namun demikian masih dijumpai kekambuhan sekitar 30\%-40\% dan 80\% di antaranya meninggal akibat metastasis, 20\% dapat sembuh dengan terapi lini kedua. Maka sejak tahun 1970an telah dilakukan beberapa penelitian yang berkaitan dengan terapi ajuvan dan neoajuvan. ${ }^{5-7}$ Penting untuk mengetahui faktor-faktor risiko terjadinya kekambuhan osteosarkoma yang diberi neoajuvan, agar dapat ditemukan cara maupun kombinasi terapi baru yang lebih baik sehingga akan meningkatkan angka survival. ${ }^{6}$

Tujuan penelitian untuk mengetahui karakteristik pasien osteosarkoma dalam membantu mengembangkan pengelolaan pasien anak dengan osteosarkoma di Rumah Sakit Cipto Mangunkusumo (RSCM), Jakarta.

\section{Metode}

Penelitian retrospektif dilakukan pada seluruh anak dengan osteosarkoma yang berobat ke Divisi Hematologi-Onkologi Departemen Ilmu Kesehatan Anak RSCM periode tahun 1998-2008. Data diambil dari rekam medis pasien dan dikelompokkan berdasarkan umur, jenis kelamin, lokasi tumor, ukuran tumor, tempat metastasis, pemeriksaan penunjang seperti pemeriksaan kadar alkalin fosfatase (ALP) dan laktat dehidrogenase (LDH), bone scan serta kemoterapi yang diberikan berupa neo-adjuvan atau hanya adjuvan. (Tabel 1).

Diagnosis osteosarkoma ditegakkan atas dasar anamnesis seperti timbul nyeri tanpa teraba masa di tulang yang terkena sekitar 3-6 bulan. Foto Rontgen, CT scan untuk evaluasi tumor primer dan untuk mencari metastasis dilakukan pada 22 pasien. Pemeriksaan penunjang lain berupa pemeriksaan kadar ALP dalam darah dan kadar LDH dilakukan pada 22 pasien. Kadar ALP dan LDH tersebut diukur sebelum tindakan bedah. Standar nilai normal kadar ALP di RSCM 35-390 U/L, sedangkan kadar LDH r 200$400 \mathrm{U} / \mathrm{L}$. Baku emas diagnosis osteosarkoma dengan pemeriksaan histologi patologis. Semua pemeriksaan penunjang tersebut dilakukan di RSCM.

Kemoterapi yang diberikan adalah kombinasi cisplatinum $100 \mathrm{mg} / \mathrm{m} 2$, doksorubisin $25 \mathrm{mg} / \mathrm{m} 2$ dan ifosfamide $3000 \mathrm{mg} / \mathrm{m} 2$. Untuk terapi neoajuvan diberikan tiga siklus. Setelah mendapat neoajuvan, pasien langsung menjalani tindakan bedah/operasi berupa amputasi atau limb sparing. Dilanjutkan kembali dengan pemberian kemoterapi adjuvan dengan menggunakan kombinasi tiga obat sitostatik tiga siklus.

Semua tindakan operasi dilakukan di Departemen Bedah Ortopedi RSCM. Pada beberapa kasus sulit, dilakukan pembahasan bersama (clinico-pathologycal conferrence/CPC) dengan melibatkan beberapa departemen, di antaranya Ortopedi, Patologi Anatomi, Radiologi/ Radioterapi, Ilmu Kesehatan Anak, dan Penyakit Dalam. Dalam pertemuan tersebut dibahas tentang stadium tumor, rencana tindakan bedah yang akan diambil, dan penentuan prognosis.

\section{Hasil}

Dalam jangka waktu 1998-2008 terdapat 23 pasien osteosarkoma dengan usia antara 9-15 tahun (median 13,2 tahun), terdiri dari 16 laki-laki dan 7 perempuan. Semua pasien dikirim oleh Departemen Bedah Ortopedi ke Departemen Ilmu Kesehatan Anak RSCM untuk mendapatkan kemoterapi.

Enam pasien didahului dengan riwayat trauma pada ekstremitas yang terkena dan terdapat 9 pasien dengan gizi baik. Berdasarkan lokasi tumor, 14 pasien menderita tumor di femur, 7 tibia, serta humerus dan kruris masing-masing 1 pasien. Tempat terbanyak yang terkena osteosarkoma adalah femur bagian distal pada 12 orang pasien, diikuti tibia proksimal 6 pasien. Pemeriksaan bone scan dilakukan pada semua pasien dan tidak menunjukkan metastasis di tulang lain. Pada pemeriksaan CT scan paru dijumpai metastasis pada 5 di antara 15 pasien (Tabel 1).

Hasil pemeriksaan histopatologis yang dilakukan dengan cara mengambil jaringan tumor menggunakan biopsi jarum halus (fine needle biopsy), menunjukkan 5 tipe osteogenik, 4 periosteal, 3 tipe blastik, dan 2 tipe konvensional. Pada 9 pasien jenis osteosarkoma tidak dapat diketahui dengan pasti, diagnosis osteosarkoma ditetapkan berdasarkan pertemuan CPC.

Hasil pemeriksaan ALP dan LDH yang dilakukan pada 22 pasien, menunjukkan peningkatan kadar ALP pada 20 pasien dan peningkatan kadar LDH pada 15 pasien. Nilai rentang LDH 165-2139 rerata 679, ADL 44-10469 rerata 1733.

Sebagian besar (15 pasien) datang dalam keadaan inoperable sehingga diputuskan untuk pemberian 
kemoterapi neo-adjuvan. Satu pasien datang ke divisi Hemato-Onkologi pasca amputasi $1^{1 / 2}$ bulan karena osteosarkoma tibia kiri proksimal. Dirawat selama 3 hari dengan sesak karena efusi pleural bilateral yang terbukti mengalami metastasis paru dan kemudian meninggal. Pada pasien ini tidak sempat dilakukan pemeriksaan ALP dan LDH maupun pemberian kemoterapi.

Dua puluh dua pasien mendapat kemoterapi dengan perincian 15 pasien mendapat kemoterapi neoajuvan, 5 pasien mendapat ajuvan yang semuanya telah dilakukan amputasi sebelumnya, 2 pasien lainnya

Tabel 1. Sebaran pasien osteosarkoma berdasarkan karakteristik klinis dan laboratorium $(n=23)$

\begin{tabular}{llc}
\hline Parameter & & Jumlah \\
\hline Usia (tahun) & $<10$ & 5 \\
& $\geq 10$ & 18 \\
Jenis kelamin & Laki-laki & 16 \\
& Perempuan & 7 \\
Tumor primer & Femur & 14 \\
& Tibia & 6 \\
& Humerus & 1 \\
Metastasis & Kruris & 1 \\
Gambaran PA & & 5 \\
\multirow{2}{*}{ CT-scan tulang } & Osteogenik & 5 \\
& Periosteal & 4 \\
CT-scan paru & Blastik & 3 \\
& Konvensional & 2 \\
& Unknown & 9 \\
& Metastasis (+) & 0 \\
& Metastasis (+) & 5 \\
\hline
\end{tabular}

LDH: lactic dehydrogenase, ALP: alkaline phosphatase,

Tabel 2. Pengobatan dan outcome pasien dengan osteosarkoma

\begin{tabular}{llc}
\hline Pengobatan & & $\mathrm{n}$ \\
\hline Kemoterapi & Neo-adjuvan (NA) & 15 \\
& Adjuvan (A) & 5 \\
Tindakan bedah & Kombinasi NA + A & 2 \\
& Amputasi & 10 \\
Outcome & Limb sparing & 5 \\
& Hidup (dalam terapi) & 8 \\
& Hidup (selesai terapi) & 2 \\
& Residif & 1 \\
& Meninggal & 5 \\
& Lost to follow-up & 6 \\
\hline
\end{tabular}

mendapat neoajuvan, limb sparring yang dilanjutkan dengan ajuvan kemoterapi (Tabel 2). Lima orang pasien meninggal dengan sebab kematian sepsis pada 3 pasien dan metastasis paru pada 2 pasien. Dua pasien pulang atas permintaan sendiri (1 pasien dengan kondisi sangat memburuk karena sepsis, diduga meninggal di rumah), 6 pasien tidak dapat dimonitor dan 6 pasien masih dalam perawatan. Terdapat 10 pasien yang masih datang untuk berobat, 2 di antaranya sudah selesai menjalani pengobatan dan 8 lainnya masih menjalani program terapi osteosarkoma berupa kemoterapi.

\section{Diskusi}

Osteosarkoma merupakan tumor ganas primer tulang yang tersering dijumpai. Beberapa penulis menyatakan bahwa usia terbanyak pasien osteosarkoma adalah remaja dengan puncak usia 15-19 tahun. Usia lanjut menempati urutan kedua. ${ }^{1-4,8}$ Pada penelitian kami median usia 13,2 tahun.

Penyebab timbulnya osteosarkoma belum diketahui dengan pasti. Beberapa faktor yang diduga sebagai pemicu adalah trauma, infeksi virus, radiasi, dan paparan zat kimia/alkylating agent. Selain itu osteosarkoma dapat dijumpai pada beberapa kelainan genetik seperti penyakit Paget dan retinoblastoma herediter. Pada beberapa osteosarkoma dijumpai penurunan fungsi gen supresor tumor yaitu gen $\mathrm{p} 53$ dan RB (retinoblastoma)., ${ }^{2,4}$

Di dalam kepustakaan, dikemukakan urutan lokasi tumor tersering adalah femur distal, diikuti oleh tibia proksimal, humerus proksimal dan fibula proksimal. Osteosarkoma pada tulang rangka lainnya atau tulang-tulang kraniofasial biasanya ditemukan pada pasien lebih tua. ${ }^{1-4}$ Di Departemen IKA RSCM lokasi tumor tersering adalah femur distal pada 12 pasien dan tibia proksimal pada 5 pasien, di antara 23 anak yang diteliti.

Ukuran tumor dapat dipakai sebagai faktor untuk menentukan prognosis. Ukuran tumor yang kecil $(<5$ $\mathrm{cm})$ sebelum kemoterapi akan mempunyai prognosis yang lebih baik bila dibandingkan ukuran tumor yang besar $(>15 \mathrm{~cm}) .{ }^{4}$ Pada penelitian kami diukur lingkar ekstremitas yang terkena tumor, dibandingkan dengan diameter ekstremitas yang sehat, dan semua ukuran yang didapatkan lebih dari $30 \mathrm{~cm}$. Pasca neoajuvan tidak didapat data, namun dijumpai pengecilan masa tumor. 
Kadar ALP dan LDH diukur sebelum tindakan kemoterapi atau operasi. Kadar normal ALP bervariasi terhadap umur dan jenis kelamin. Beberapa peneliti menggunakan kelompok umur 2-10 tahun 100-300 U/L, wanita 10-13 tahun 110-400 U/L, laki-laki 13-15 tahun 125-500 U/L dan usia 20-40 tahun 25-100U/L. ${ }^{6}$ Dalam penelitian kami nilai normal kadar ALP 35-390 U/L dan LDH 200-400 U/L.

Pada $40 \%$ pasien dijumpai peningkatan ALP, hal tersebut tidak menggambarkan luasnya penyakit meskipun demikian dapat digunakan sebagai penentu prognosis. Peningkatan LDH dijumpai pada 30\% pasien osteosarkoma tanpa metastasis. ${ }^{4}$ Pada penelitian kami pemeriksaan kadar ALP hanya dilakukan satu kali sebelum kemoterapi dan sebelum tindakan bedah. Beberapa peneliti hanya mengukur kadar ALP dilakukan sebelum kemoterapi atau setelah operasi. Bramer $\mathrm{dkk},{ }^{10}$ menyarankan untuk pemeriksaan ALP sebelum dan sesudah kemoterapi, karena perubahan ALP setelah kemoterapi dapat digunakan sebagai faktor prediksi respon kemoterapi dan angka survival osteosarkoma stadium tinggi pada orang dewasa. Pemeriksaan tersebut mudah dan murah, sehingga bila digabungkan dengan faktor lain dapat menentukan prognosis dengan lebih baik. Untuk menentukan prognosis, selain pemeriksaan ALP dapat juga dengan pemeriksaan LDH. Berdasarkan Multi-Institutional Osteosarcoma Study, peningkatan kadar LDH saat diagnosis ditegakkan merupakan satusatunya petanda yang menunjukkan prognosis buruk pada pasien osteosarkoma ekstremitas tanpa metastasis yang telah mendapat ajuvan. ${ }^{4}$

Sembilan pasien tidak diketahui hasil pemeriksaan histopatologi. Hal ini sangat mungkin disebabkan oleh pengambilan jaringan tumor hanya dengan cara biopsi jarum halus, sehingga kurang representatif dan tim CPC memutuskan untuk diobati sebagai osteosarkoma. Dua pasien lainnya mendapat neoajuvan, limb sparring yang dilanjutkan dengan ajuvan kemoterapi. Perlu upaya untuk perbaikan dalam penentuan stadium tumor untuk menentukan prognosis. Pemeriksaan kadar ALP perlu dilakukan sebelum dan setelah kemoterapi. Demikian pula dengan pencatatan lainnya seperti pengukuran lingkar tumor dengan baik.

Pencarian metastasis pada pasien osteosarkoma perlu dilakukan. Tempat tersering ditemukan metastasis adalah paru, sehingga perlu melakukan pemeriksaan radiologis, CT scan dan MRI. Pada osteosarkoma, sampai saat ini $C T$ scan paru merupakan pemeriksaan penunjang standar yang harus dilakukan, walau terkadang tidak semua metastasis/nodul akan tampak. Penyebaran mikrometastasis pada umumnya secara hematogen, maka pencarian metastasis juga dapat dilakukan dengan melacak sel tumor dalam sumsum tulang atau darah tepi. Pemeriksaan tersebut murah dan cepat. ${ }^{7,11}$

Dalam beberapa pustaka dinyatakan bahwa metotreksat terutama dosis tinggi merupakan pilihan obat yang baik untuk pengobatan osteosarkoma. Penggunaan metotreksat masih diperdebatkan oleh para ahli karena beratnya efek samping yang disebabkan oleh tingginya kadar obat tersebut dalam darah setelah 24-48 jam pemberian. Kelompok ahli dari Eropa mendukung penggunaan metotreksat karena respon dan angka survival yang tinggi. Protokol yang menggunakan metotreksat dosis tinggi (8-12 $\mathrm{g} / \mathrm{m}^{2}$ ) yang dikombinasi dengan doksorubisin dan cisplatin menghasilkan periode bebas tumor selama lima tahun $41 \%$, sedangkan dengan penggunaan doksorubisin dan cisplatin saja 57\%. Beberapa peneliti sependapat bahwa metotreksat dosis tinggi, cisplatin, doksorubisin dan ifosfamid merupakan sitostatik yang paling efektif untuk osteosarkoma. ${ }^{1,7}$ Dalam penelitian kami pemberian kemoterapi baik neoajuvan maupun ajuvan hanya menggunakan cisplatin, adriamisin dan ifosfamide, tanpa menggunakan metotreksat.

Konsep neoajuvan telah digunakan sejak duapuluh lima tahun yang lalu, dengan tujuan mengatasi metastasismikro serta memudahkan prosedur operasi karena ukuran tumor akan mengecil, vaskularisasi daerah tumor akan berkurang, dan gambaran histologis menunjukkan perbaikan. ${ }^{2,12,13}$

Dengan makin majunya teknologi maka selain amputasi, saat ini dilakukan pula tindakan berupa limb sparing. Keuntungan limb sparing adalah pengembalian fungsi ekstremitas lebih baik daripada kasus yang diamputasi, sedangkan aspek psikologis belum jelas perbedaannya. Selain limb sparing lebih mahal dan membutuhkan pengawasan yang lebih intensif dibanding amputasi maka pada limb sparing harus dihindari dari infeksi, nekrosis, tromboemboli. Angka rekurensi pada limb sparing lebih tinggi bila dibandingkan dengan amputasi. ${ }^{4,14}$ Dalam kasus di RSCM lima pasien dengan tindakan limb sparing dan sepuluh pasien dengan amputasi. Amputasi merupakan satu-satunya pilihan bagi pasien osteosarkoma yang telah menembus saraf dan atau pembuluh darah serta keterlibatan jaringan lunak yang sangat luas sehingga tidak mungkin untuk menyelamatkan tungkai. 
Prognosis osteosarkoma tergantung pada kadar ALP dalam serum, volume tumor, tata laksana, bebas tidaknya tepi sayatan dari sel tumor dan respon histologi terhadap terapi preoperatif, serta ada tidaknya metastasis. Saat ini, kombinasi kemoterapi neoadjuvan dan adjuvan serta tindakan bedah merupakan terapi yang sangat efektif untuk meningkatkan angka survival lima tahun hingga $60,1 \% .4,6,7,10,15$

\section{Daftar Pustaka}

1. Bielack SS. Osteosarcoma. Dalam: Agarwal BR, Perilongo G, Wacker P, Eden T, penyunting. SIOP Education Book 2006, $38^{\text {th }}$ Congress of the International of Pediatric Oncology: Sep 17-21, 2006; Geneva, Switzerland. Swiss; 2006.h.99-112.

2. Bielack SS, Bernstein ML. Osteosarcoma. Dalam: Voute PA, Barret A, Stevens MCG, Caron HN, penyunting. Cancer in children, clinical management. Edisi ke-5. New York: Oxford University Press; 2005.h.280-300.

3. Hayden JB, Hoang BH. Osteosarcoma: basic science and clinical implications. Orthop Clin N Am 2006; 37:1-7.

4. Link MP, Gebhardt MC, Meyers PA.Osteosarcoma. Dalam: Pizzo PA, Poplack DG, penyunting. Principles and Practice of Pediatric Oncology. Edisi ke-4. Philadelphia: Lippincott Williams \& Wilkins; 2002.h.1051-89.

5. Bacci G, Longhi A, Versari M, Mercuri M, Briccoli A, Picci P. Prognostic factors for osteosarcoma of the extremity, treated with neoadjuvant chemotherapy: 15-year experience in 789 patients treated at a single institution. Cancer 2006;106:1154-61.

6. Bacci G, Longhi A, Ferrari S. Prognostic significance of serum alkaline phosphatase in osteosarcoma of the extremity treated with neoadjuvant chemotherapy: recent experience at Rizzoli Institute. Oncol Reports 2002;9:171-5.
7. Bacci G, Briccoli A, Ferrari S, Donati D, Longhi A, Bertoni F, dkk. Neoadjuvant chemotherapy for osteosarcoma of the extremities with metastases at presentation: recent experience at the Rizzoli Institute in 57 patients treated with cisplatin, doxorubicin, and a high dose of methotrexate and ifosfamide. Ann Oncol 2003;14:1126-34.

8. Rech Â, Castro CG, Mattei J, Gregianin L, Di Leone L, David A, dkk. Clinical features in osteosarcoma and prognostic implications. J Pediatr 2004;80:65-70.

9. McNair JD, Damron TA, Landas SK, Ambrose JL, Shrimpton AE. Inheritance of osteosarcoma and Paget's disease of bone. A familial loss of heterozygosity study. J Mol Diag 2001;3:171-7.

10. Bramer JAM, Abudu AA, Tillman RM, Carter SR, Sumathi VP, Grimer RJ. Pre- and post-chemotherapy alkaline phosphatase levels as prognostic indicators in adults with localiced osteosarcoma. Eur J Cancer 2005;41:2846-52.

11. Bruland OS, Hoifodt H, Saeter G, Smeland S, Fodstad O. Hematogenous micrometastases in osteosarcoma patients. Clin Cancer Res 2005;11:1-8.

12. Wilkins RM, Cullen JW, Camozzi AB, Jamroz BA, Odom L. Improved survival in primary nonmetastatic pediatric osteosarcoma of the extremity. Clin Orthop Related Research 2005; 438:128-36.

13. Cullen JW, Jamroz BA, Stevens S. The value of serial arteriography in osteosarcoma: delivery of chemotherapy, determination of therapy duration and prediction of necrosis. J Vasc Interv Radiol 2005; 16:1107-19.

14. Di Caprio MR, Friedlaender GE. Malignant bone tumors: limb sparing versus amputation. J Am Acad Orthop Surg 2003;11:25-37.

15. Wilkins RM, Cullen JW, Odom L. Superior survival in treatment of primary nonmetastatic pediatric osteosarcoma of the extremity. Ann Surg Oncol 2003;10:498-507. 